Article

\title{
Power, Ideology and Structure: The Legacy of Normalization for Intellectual Disability
}

\author{
Murray K. Simpson \\ School of Education and Social Work, University of Dundee, Dundee, DD1 4HN, UK; E-Mail: m.k.simpson@dundee.ac.uk
}

Submitted: 15 November 2017 | Accepted: 2 February 2018 | Publication: 17 May 2018

\begin{abstract}
Since its first formulation in English, the 'principle of normalization' has had a profound impact on policy and practice in the field of intellectual disability. Over the past fifty years, normalization, and Social Role Valorization, have drawn on liberal humanist philosophy, adopting varied and complex positions in relation to it. This article will consider an apparent structural correspondence between a discourse of 'liberal equality' with versions of normalization that emphasised conformity to social norms, and those drawing primarily on 'liberal autonomy', emphasising independence and self-determination of people with intellectual disabilities. Despite this seeming correspondence, the article eschews a structuralist account in favour of a discursive and rhizomatic model, in which the philosophical elements are seen as tactical forces deployed in the pursuit of wider strategic ends. The article concludes by highlighting paradoxes in contemporary thinking that can be traced to the legacy of normalization, specifically, the tensions between sameness, difference, equality and independence.
\end{abstract}

\section{Keywords}

Deleuze; disability; discourse analysis; ethics; Foucault; ideology; intellectual disability; normalization principle; power; structuralism

\section{Issue}

This article is part of the issue "Global Perspectives on Disability", edited by Shaun Grech (The Critical Institute, Malta) and Karen Soldatic (Western Sydney University, Australia).

(C) 2018 by the author; licensee Cogitatio (Lisbon, Portugal). This article is licensed under a Creative Commons Attribution 4.0 International License (CC BY).

\section{Introduction}

The principle of normalization has been identified by numerous authors as the single most significant model for policy and services in the field of intellectual disability in the past fifty years - a fact that holds true in virtually all English-speaking countries around the world, as well as many others (see, for example, Caruso \& Osburn, 2011; Emerson \& McGill, 1989; Keith \& Keith, 2013; Kendrick, 1999; Race, 2002). Whilst not always explicitly cited in policy and legislation, it had a significant influence on the United Nations (1971) Declaration on the Rights of Mentally Retarded Persons; and, in the United Kingdom, both on the white paper, Better Services for the Mentally Handicapped (Department of Health and Social Security, 1971) and The Report of the Committee of Enquiry into Mental Handicap Nursing and Care (Jay, 1979), which ushered in policies of deinstitutionalization; whilst in current policy for people with intellectual disabilities ${ }^{1}$ (Department of Health, 2001; Scottish Government, 2013), it continues to be the implicit theoretical pivot upon which services shifted to a non-institutional basis (Johnson, Walmsley, \& Wolfe, 2010). As Mathews suggests:

[It] had a major impact on social policy in the United Kingdom and the provision of care services to disabled people, and can be seen as being an influential driver in the closure of long-stay institutions and the development of more personalised, community-based alternatives. (2017, p. 1364)

Although it did set out relatively clear objectives for reformed policy and services, its principal target, at least in the early years, was the institution or hospital. In

\footnotetext{
${ }^{1}$ References to 'persons with intellectual disability', 'mental retardation' and so on, refer only to conceptual categories in which some are situated and others not; they do not refer to any intrinsic characteristics of such individuals.
} 
more recent decades, in what Altermark (2017) calls the 'post-institutional' era, there has been a shift towards discourses of 'citizenship'. However, as he also notes, these have involved transformations of power, rather than its disappearance.

This leaves a key question for the present as to whether normalization continues to have any relevance or contribution to contemporary thinking in intellectual disability policies and practices. Whilst even some sympathizers (e.g. Race, 2002) have suggested that it is time to 'move on' from normalization debates, by critically examining the development of two broad approaches to normalization and philosophy, we can see the continued value of sociological critique in unblocking stultified thinking. Two strands, or strategies, have linked institutional critiques and putatively 'progressive' thinking to two different aspects of liberal humanism-equality and autonomy-with the former being more closely aligned with behavioural psychology, and its emphasis on adherence and adaptation to behavioural norms, and the latter more in evidence in thinking around community-based services and the promotion of independence. Needless to say, these are broad characterizations of approaches that in reality exhibited far less consistency or coherence. They were not entirely distinct approaches to normalization, and the elements of liberal philosophy are not mutually exclusive. The aim of this article is to highlight and account for the relative balance that was given in different texts to the two elements and to explore their connection to service frameworks in order to demonstrate the essentially tactical nature of ethical principles within service models like normalization. The hope is that, in doing so, it will open up new spaces in which ethical claims can be made and the rubric by which they can take form.

The critique will trace each of these strands in turn and show how each connects with other, wider strategies of power. It will demonstrate how these lines come together within the discourse of normalization in apparent structural correspondences. However, whilst appearing to suggest a structural correlation, the article will conclude that only a less deterministic, discursive approach can account for this association. Although the article draws on international literature, it is situated primarily in the context of the United Kingdom, where normalization and Social Role Valorization (SRV) have been less hegemonic than elsewhere.

Whilst such an analysis cannot provide a set of solutions to agreed upon problems, or even goals, there being no such agreement or possibility thereof, it can help to free up aspects of thinking that have become sedimented and stuck. By putting the obvious and self-evident back into play as contestable objects'intellectual disability' most of all-new ways of thinking are more likely to be opened up. So, although normalization tends only to be mentioned in passing in more recent general texts on intellectual disability policy (e.g. Goff \& Springer, 2017; Richards, Brady, \& Taylor, 2015; Sturmey \& Didden, 2014), this largely reflects how its as- sertions and values have become implicit, producing an assumed conceptual foundation for contemporary discourse (Altermark, 2017). Gilbert, Cochrane and Greenwell $(2005$, p. 293), for example, suggest, that it "has been transformed into a discourse of citizenship with people with learning disabilities now managed within specialised spaces in the community which remain supervised by professionals", whilst Corbett (2011, p. 276) credits it with the "significant politicisation of people with intellectual disabilities". Nonetheless, there remain underlying assumptions that are particularly problematic because of the ways in which they can obscure the discursive and non-discursive effects that normalization continues to play in constituting the field of intellectual disability: its concepts, subjectivities, interventions, and so forth. As this article will demonstrate, it is at this level that a historicized critique of intellectual disability must operate, rather than dealing only with current policies, and service theories and models. Failure to do so will result in the continual replication of variants of the present.

\section{Liberal Equality and Behavioural Conformity}

The first strand, then, is that linking the development of the principle of normalization as a loose and sometimes contradictory discourse and operant conditioning, in particular, the way in which the former was used as an instrument of the latter-observations of mutual reinforcement and contradiction notwithstanding (e.g. Emerson \& McGill, 1989). As Clarke and Clarke (1974, p. 7) suggested, behavioural techniques for the teaching of social and employment skills "were [later] termed 'normalization'", whilst Schalock (2004) observed that the development of adaptive behaviour was 'integral' to principles of normalization. Normalization also served as a tactical weapon for psychology against medically oriented institutions in favour of community facilities, which, at least in theory, had a more developmental orientation, even if the realities of deinstitutionalisation didn't always accord with these aims (Felce, 1996; Flynn, 1980). When normalization took root in North America, the force of the human rights argument was largely rooted in a certain tradition of human rights which existed in the USAbroadly Lockean in orientation-as well as to a specific period when that tradition received particular political emphasis (see, for example, Wolfensberger, 1971). Not only was it a time when there was a general critique of institutions and institutionalisation (Goffman, 1961), but it was also one that witnessed anti-Vietnam war protests and civil rights unrest. One typical ideological strategy employed for the political advancement of normalization was to appeal to the common humanity between 'people with mental retardation'-and this word was itself emphasized-and others, with a corresponding attack on the 'de-humanizing' institutions and practices therein. Central to arguments for normalization was the recognition of "a claim to humanity which they share with 
the non-handicapped" (Ryan \& Thomas, 1987, p. 130), though, as Wolfensberger (1980) made clear, it would be mistaken to draw a simple equation between the two. Normalization may depend on humanization, but the latter does not necessarily lead to, or imply commitment to, the former.

The specific philosophical construction of personhood for the 'retarded' individual was not by any means unique to the issue of retardation. Nonetheless, there is ample evidence of this shifting view being tactically significant for an empiricist psychology in defining the personhood of the retarded individual. This was particularly true in the ways in which it further dichotomised soul and body, alienating consciousness from behaviour. Gold (1980, p. 19) illustrated this point with his insistence that trainers focused on tasks and behaviour as opposed to "feelings", which would constitute "manipulation". As Foucault (1979) observed, the deployment of the soul as human essence was fundamental to the coexistence of the empirical sciences of human behaviour, with humanist politics and ethics. Foucault describes its function as a 'reality reference', upon which, through the medium of the body:

Various concepts have been constructed and domains of analysis carried out: psyche, subjectivity, personality, consciousness etc.: on it have been built scientific techniques and discourses, and the moral claims of humanism. (Foucault, 1979, pp. 29-30)

For the principle of normalization, the key function, or effect, of the soul was to establish a commonality and equality between those deemed to be and not to be 'retarded'. In addition, it depended upon a specific relationship between the retarded person, his or her body, and the observing gaze of the psychologist.

Of the various key components that make up liberal humanist philosophy, that of 'liberal equality' - equality before the law, equality of opportunity, as citizens in a democratic polity, etc. - was particularly significant in this strand of normalization. As already noted, the claims of normalization against the dehumanizing institution were invariably underpinned by assertions of this common humanity. The role of psychology was, perhaps, subtler, though arguably much more profound in forming the conditions of emergence for normalization (Simpson, 1998). Whilst at pains to say, unconvincingly to critics (see e.g. Brown \& Smith, 1989; Perrin \& Nirje, 1985), that "the goal [of normalization] is not to impose social conformity", it was, nonetheless, "to prevent or reverse involuntary or unconscious deviancy" (Wolfensberger, 1970, p. 68; see also, Wolfensberger, 1972). Behaviourism introduced another form of normalization, viz. the normalizing actions of disciplinary power. Thus, there were, "two...basic variables that can be manipulated for the client's benefit: his environment and, as a result of the manipulation of his environment, his behavior" (Meyerson, Kerr, \& Michael, 1974, p. 377).
In this way, behaviour was reduced to the level of a 'variable', subject to expert scrutiny and control, the aim of which was to produce social integration through behaviour change-though also attitudinal and service changes. In turn, the separation and bracketing of the 'ethical' created a distinctive hierarchy of need. Thus, skills of money use or the prevention of shrieking in public were deemed to be more important on the scientific curriculum than the creation or appreciation of art. As Wolfensberger and Thomas (2007, p. 283) suggested, competence development should be directed towards the enhancement of creating and sustaining valued social roles, not with "competency for its own sake". Consequently, the 'mentally retarded' subject became an increasingly complex and managed space characterized by the containment of responsibility and self-direction, within an encompassing space of irresponsibility and alienated will.

Although often downplayed in relation to other factors, such as the putatively sociological basis of normalization (Wolfensberger, 1970, 1972, 1975), the impact of developments in psychology in the post-war period were highly significant for the emergence of normalization. At the same time, the picture was a complex one and Parmenter (2004) documents the ways in which behavioural psychology drove and was driven by the demands of noninstitutional models of service provision. Behavioural research demonstrated what could be achieved in terms of the acquisition of social skills (Francey, 1960; Tizard, 1964) and employment skills (O'Connor \& Tizard, 1956), as well as the reduction in 'maladaptive' behaviours (Beier, 1964), and a wide range of other aspects of learning and behaviour through operant conditioning (Denny, 1964). As Yates, Dyson and Hiles (2008) note, the individual tended to become obscured within normalization, which reduced its targets merely to functions of the social. This problem, they argue, is borne precisely out of irreconcilable tensions between the humanism of normalization, an essentialist view of impairment and the failure to conceive of the subject as an effect of power and knowledge. These problems are evident also in the second broad tradition of normalization, considered next.

\section{Liberal Autonomy and the Self-Directed Life}

Running through the dominant discourse of normalization, then, was a thread of similitude that linked together the scientific pedagogy of behaviourism and the ideology of liberal equality: a behavioural, disciplinary normality, and a shared human identity. However, although Wolfensberger's approach, or, rather, approaches, may have dominated the field, theoretically at least, they were by no means the only ones. The apparent structural correspondence between liberal humanism and strategies of governance can also be found in another strand of normalization. In this instance, the broad correlation is between an ideological base drawing principally on liberal autonomy and a service strategy aimed at maximiz- 
ing choice and independence. Here the common thread is quite different, rather than commonality between people, it emphasizes human individuality and uniqueness via human rights and autonomy. Although normalization was not centrally about 'rights' (Wolfensberger, 2002), the discourse of 'rights' was very much in evidence from the outset of the normalization's development. BankMikkelsen (1964) identified the recognition of the full and equal rights of citizenship for the people with intellectual disabilities as central to the pioneering developments in Denmark that first introduced the principle of normalization.

Several factors contributed to the fracturing of the relative theoretical homogeneity that normalization enjoyed in the 1970s. One of these was the widespread cooption of deinstitutionalisation into government policy in Western and Northern Europe, North America, and Australasia. In many of these cases, the policies, often under a general rubric of 'community care', aimed at maximizing choice and independence, most especially in countries and states where neo-liberal social policies were beginning to be pursued. Nirje $(1969,1972)$ had argued from the outset that the right to make or influence choices affecting one's life was fundamental to the principle of normalization at both an individual and collective level.

They know what they are talking about, and they know that they are describing the realities of their existence....They are acting as citizens with the same right to be respected as others. (Nirje, 1972, p. 189)

The UK government policy framework of 'community care', or the service model of 'an ordinary life' (King's Fund, 1980, 1984) provide good examples of the emphasis on independence, both in the sense of self-reliance, i.e. of individuals, families and communities, and selfdetermination. In this formulation, 'normal' played a much more straightforward function as the creation of services that allowed for lives as ordinary, unfettered and self-determined as possible (e.g. Towell, 1988). As with Nirje (1972), the key role of service users as experts on their own circumstances and needs was central (Gathercole, 1988). From the perspective of public authorities providing and commissioning social services, the promotion of independence was also frequently linked to reduction in public support.

This conceptual approach emphasised the individual and his or her right to self-determination. Here, a typically more politicised approach both celebrated difference whilst also challenging the oppression related to it (see e.g. Szivos \& Travers, 1988). Confronting the alleged emphasis on conformity to dominant social norms-white, masculine, middle class-Szivos asked: "Why should people [with intellectual disabilities] not be allowed to feel positively about what is unique about them?" (1991, p. 29, emphasis added)
By contrast, the normalizing pedagogy of the psychological strand exhibited a tendency to over-ride selfdetermination wherever it resulted in decisions and options that might not be the most 'socially valued'most especially after Wolfensberger's (1983) conceptual reorientation towards SRV, which resulted in an even greater ambivalence towards the whole question of personal choice (see e.g. Wolfensberger, 2002). For Wolfensberger and Thomas (2007), the exercise of one's rights was firmly subordinated to cultural normativity and adaptive competence for deviant and devalued persons, rather than placing rights and choice at the centre, as Mathews (2017) suggested it did. Services were expected to implement support for rights in ways that developed "adaptive personal autonomy...[in] culturally appropriate and valued [ways, for the]...responsible exercise of their rights" (Wolfensberger \& Thomas, 2007, p. 225 , emphasis in original). The exercise of personal autonomy in ways that were 'maladaptive' was to be "governed by discipline, self-control, and a sense of responsibility" (Wolfensberger \& Thomas, 2007, p. 225).

\section{Normalization and Ideology: Structure and Discourse}

As noted, there were sharp points of disjuncture in Wolfensberger's own work, most notably with the shift to SRV-cementing his focus on creating and maintaining valued social roles as the key to protecting devalued social groups from exclusion and harm-and times when threads came together only to part later, highlighting the need not to become concerned with authorial biographies and oeuvres (Foucault, 1972). Rather than attend to the evolution of any particular author's thinking, I have tried to present an apparent structural correspondence between certain strategies of power and ideological formations in the discourse on normalization. Specifically, one based on commonality ('human essence' as an ideology underpinning the strategy of 'behavioural competence'), and another based on individuality (with 'liberal autonomy' serving as the ideological basis for 'independence').

There is a certain attractive neatness to a structural account for these correspondences. What is lacking, however, is any apparent mechanism or structure of causation. Without recourse to the founding subject-there being no reason for supposing that authors are individually, and simultaneously, engaged in a conscious tactical appropriation of ideological elements solely in pursuance of larger power strategies-there is a hiatus in the accounting for any determination. More widely, this was, of course, one of the principal reasons for the general demise of structuralist theory (Nayar, 2014).

Post-structural approaches, with the general emphasis on 'discourse', understood as constitutive, though not determining, of subject positions (Sullivan, 2005), seem more promising analytically. In a study of the life sci- 
ences, Valle (1997) suggests three dimensions for the analysis of discourses:

(i) the subject matter of the texts and their general rhetorical structure; (ii) the implicit or explicit 'recipient' or addressee of the text; and (iii) the presence or absence of an explicit text 'motivation', i.e. statement of purpose. (Valle, 1997, p. 79)

All three of these elements can be observed in this study of normalization and liberal philosophy. The analysis has rested on the study of the elements and structure of the discourse, and it is from here that the central problematic has arisen. In the second and third place, several implicit-and sometimes quite explicit-target audiences and objectives can be discerned, particularly relating to the general anti-medical, anti-institutional agenda. However, as the analysis has shown, the motivations and addressees are multiple, highly layered and inconsistent. In addition, the second and third components, like Kuhnian theory of scientific development (Kuhn, 1996), lead this approach to lapse into a form of collective psychology based around inter-subjective agreement on truth and meaning (Gutting, 1989). A Foucauldian approach, however, more thoroughly excludes the action of the subject from the analysis:

The rules of discourse are not rules which individuals consciously follow....Indeed, the place, function and character of the 'knowers', authors and audiences of a discourse are also a function of these discursive rules. (Philp, 1990, p. 69)

In addition, this approach allows for the generalised account given here, whilst also accounting for the, often significant, exceptions to the correspondences suggested. Foucault (1981, p. 100) notes that elements and bodies of discourse circulate with "tactical polyvalence", pressed into service first for one, then for another strategy of power, sometimes simultaneously for two contradictory ones. Equally, two apparently exclusive elements may be held in tension within the one power-knowledge complex. For this reason, we must also avoid the approaches based merely on the play of binaries.

The principle of normalization was simultaneously: a concept, or series of concepts; a wider discursive field; and a technology of power. Little wonder then that its proponents so often felt compelled to correct the perceived errors of others in interpreting or applying it: academics, professionals, policy makers and one another (e.g. Emerson, 1990; Nirje, 1992; O’Brien, 1981; Perrin \& Nirje, 1985; Wolfensberger, 1980, 2002), or, as Caruso and Osburn (2011, p. 194) put it, "safeguarding against...degradation". Deleuze and Guattari's (1988) figure of the 'rhizome' provides a useful analogy here. Like the rhizomatic tuber, normalization proliferated beyond the control of its designers, mutating and altering its growth to changing conditions. There was never a single point or strand that could be called the 'true' or 'essential' one, not even in a founding sense-perhaps most of all in a founding sense-to which we might return or aspire. Furthermore, as Shildrick and Price (2006) note, the rhizomatic proliferation of knowledge is not something to be wary of or disappointed in. At worst, there is an inevitability to its steady operations, and, in fact, it constantly opens up new inclusive opportunities for such developments, particularly at the micro-level. Goodley (2007; see also Fisher \& Goodley, 2007), for example, has shown how 'rhizomatic' counter-narratives from the mothers of disabled babies have helped produce 'shelter' and resistance from dominant ones, as well as leading new forms of subjectivities.

Whilst here is not the place to develop a fully-fledged account of normalization as rhizomatic, there are a number of points to be made-following Buchanan's (2007) reading of the concept-none of which imply or require wholehearted support for the Deleuzo-Guattarian project. Firstly, the various iterations and uses of normalization that we have considered (and all the others besides) interconnect, though we must eschew the temptation to order them hierarchically and claim that any are more 'true', 'accurate' or possibly even 'helpful'. Secondly, and following from the first point, they are all facets of a whole that is simultaneously not a unity; "it is composed of dimensions...not units" (Buchanan, 2007). Thirdly, the proliferation of the rhizome is not 'reproductive', in the fashion of Wolfensberger's approach; instead, its growth is chaotic, unpredictable, generative of mutation and offshoots. Fourthly, it is an "infinitely modifiable map" (Buchanan, 2007), highlighting the fact that normalization, through ongoing critique, contains infinite future potentialities and directions of travel. Fifthly, the rhizome lacks any fixed centre or ruling signifier, which is why Wolfensberger's efforts at conceptual containment continually failed. Lastly, Buchanan (2007) notes that the rhizome is not "amenable to any structural or generative model"; normalization, in other words, is not a 'thing' that exists to be understood, clarified and refined. It is constantly being brought into being, and in ever new ways, with and through discourse and practice.

Some of the signs of this rhizomatic (re)generation are evident throughout this article. The institution provided a common focus and the conditions conducive to the deployment of a discourse of common humanity. In the post-institutional context, the field is fragmentingthe normative strategy has intensified, whilst new strategies have emerged, predicated on the new relations of power: choice, individual service planning, risk management. This does not, however, imply that discourse, even in its strictly ideological functions, is subservient to the actions of a sovereign power. Instead, this article highlights the way in which both liberal humanism and normalization deploy and are deployed, for reasons of tactical expediency, in "a multiple and mobile field of force relations, wherein far-reaching, but never completely 
stable, effects of domination are produced" (Foucault, 1981, p. 102).

The elements of philosophy explored in this article do, however, also perform an ideological function, in the sense that they play a legitimating role for certain practices and policies. They do not provide a foundational value base on which normalization can be said to rest, but neither are they ideological in the structuralist sense of that term; there is no structural determination in evidence, they have no intrinsic, singular or static connection to normalization, and have no fixed orientation or value. They signify a much more complex pattern of mutual induction, transformation and deployment of power and knowledge over a constantly shifting terrain.

\section{Conclusion}

This article has implications for common assumptions that the outcome of ethical contests is, or at least ought to be, primary and determining in shaping the life opportunities, the social and ethical position of people with intellectual disabilities, and what that might even mean (see, among others, Kittay \& Carlson, 2010; Rogers, 2016). Goodey $(2011,2016)$, by contrast, has argued that the relationship between ethics and social practices shaping 'intellectual disability' have been far more complex and contradictory throughout history in ways that are not reducible to matters of progress. Indeed, one might be tempted to wonder whether Kittay and Carlson's (2010) eponymous debate around Cognitive Disability and its Challenge to Moral Philosophy might not more accurately be reversed.

The consequences of such a study for SRV, and its accompanying service assessment tool, PASSING, are that any further attempts to purify, define and control the concept, its dissemination and application, would be seriously misguided. One of the key features of the shift from normalization to SRV, was an increasing emphasis on the nature of the concept as empirically verifiable, objective and essentially value free; the underpinning assumption being that SRV was itself subject to 'higher order' 'supraempirical' principles and values which give the system and its outcomes meaning (Thomas \& Wolfensberger, 1999). SRV, it is suggested, should be restricted to the domain of empiricism, 'What works?', and anything else is 'religion' (Thomas \& Wolfensberger, 1999); SRV itself "does not prescribe" (Wolfensberger, 2002, p. 253).

However, such a position has resulted in a certain vacillation because its proponents regard social norms and mores as both a resource for the process of valorization, as well as the primary sources of oppression (e.g. Wolfensberger, 1995). SRV reveals itself as an actively functioning system for the deployment of values, and as much more than just passively subject to the actions of ideological meta-narratives. More significantly, there can be no appeal to such 'supra-empirical' principles, since the fact-value divide on which such a supposition rests cannot be sustained. The ideological sys- tems deployed in the various iterations of normalization have been shown to have been levelled to the same shifting terrain of power-knowledge relations as the concepts they are purported to govern. The reconceptualization of normalization as SRV did nothing to overcome this. Indeed, claims to a quasi-scientific neutrality themselves carry an ideological paradox: Critics' very attempts to raise objections on ideological grounds are dismissed as fundamentally misguided on the grounds that SRV provides no guide to what ought to be done (Wolfensberger, 2002), and yet, it is surely spurious to maintain that SRV is in fact neutral about what is to be done. The mere fact of determining what is and is not directly relevant to the measurement of social value is itself a matter of value, as are the mechanisms of definition and relative weighting.

Returning to Yates et al. (2008), it is important to note also that neither normalization nor SRV have resolved the paradoxical relationship between the implied concept of the liberal subject, and the intellectually disabled subject's actual status as produced by various lines of force (see also, Simpson, 2017). The outcome of this paradox, they contend, is the, again implicit, although necessary, silencing of the impairment, 'intellectual disability', as a concept itself, leading to further conceptual confusion. Altermark (2017) also tries to problematize this subject position by recasting the recent historiography of intellectual disability. However, he does so in a way that introduces different kinds of historical simplifications to those he attempts to critique. Following Foucault's lead, Altermark objects to analyses of power that constantly privilege the state, but he himself situates historical periodsoverly monolithically-in terms of government policies. As we have seen here, the initial developments in normalization and deinstitutionalization had little to do with the state per se, beginning at a more micro and interstitial level with developments in operant conditioning.

Other tensions and conflicts are also apparent in the maintenance of SRV, for instance, in the way in which it evinces an ongoing difficulty in adopting or aligning itself with a clear system of rights. In their book on ethics and intellectual disability, for instance, Keith and Keith (2013) conclude with a section, commending SRV as the way forward, that is devoid of reference to rights and ethical theory. Also, whilst Caruso and Osburn (2011) were insistent on the need to keep 'best practice' within the tightly regulated framework of SRV, Shevellar, Sherwin and Mackay (2012), struggle to marry the top-down enforced singular model of SRV with the principles of adult education, with its participative and experiential, bottom-up approach. Whilst wishing to ground SRV training in experiential learning and reflection, they do not anticipate and address the kind of proliferation of perspectives that Wolfensberger and those carrying on his legacy were so keen to avoid. They do, however, note the inability of SRV to halt the development of oppressive institutions now flourishing in the community.

This critique problematizes two implicit paradoxes that were evident in the two approaches to normaliza- 
tion and that continue to be very much in evidence today. The first derives from the professional and conceptual manoeuvring by psychology; it is the underlying assumption that the different must be made to appear the same. Indeed, as Simpson (2014) contends, it is the very failure of mechanisms of socialisation to inculcate disciplinary self-regulation that is constitutive of intellectual disability itself. Consequently, interventions typically involve the external imposition of what would normally be acquired and assumed. The second paradox, perhaps the more significant one, can be traced directly to the second tradition of normalization, viz. the unstable and logically incoherent claim of different but equal. The basis of any putative categorical difference here can only essentialize intellectual disability. However, doing so undermines any real basis for commensurability within liberal humanism. This paradox was captured, without irony, in the title of an earlier policy framework published by the Scottish Executive, The Same as You? (2000). The title, posed as a question, both implies a difference-about which the question is being asked-whilst enquiring as to whether that difference is the same.

Given these warnings, the advancement of a progressive politics for and with people with intellectual disabilities must not imply unequivocal adherence to a particular model, or even an objective. Not simply because these are never arrived at, but because the relations of power and the constitutive bodies of knowledge are constantly shifting. As Shildrick (1997) notes:

The yearning for the certainty of absolutes has resulted historically not in justice or equality or liberty, but in the denial of moral personhood to all those categories of living beings who cannot be identified in terms of the ideal standard. But once the binary of ideal/non-ideal has been displaced, once it is acknowledged that full and final definition is always deferred, it becomes possible to seek new constructions which no longer operate on the basis of exclusion. (Shildrick, 1997, pp. 212-213)

Although, as we have seen, new constructions, whatever form they take, can shift quite easily from being instruments of liberation to ones of oppression. The neverending attempt to fix and govern a theory, such as SRV, inevitably causes us to lose sight of how fundamentally the field has changed and, therefore, the strategic possibilities of SRV itself. Paradoxically, this change is very much due to the effects of normalization itself, albeit not always in foreseen or planned ways. That is not to say, as some have done (Race, 2002), that there is no longer any purpose to be served in studying normalization, and that only SRV and associated concepts should be considered. Indeed, rhizomatic proliferation is not the reason why normalization should be ignored, it is what presents public policy with the possibility of radically new options and directions.

\section{Conflict of Interests}

The author declares no conflict of interests.

\section{References}

Altermark, A. (2017). The post-institutional era: Visions of history in research on intellectual disability. Disability \& Society, 32(9), 1315-1332.

Bank-Mikkelsen, N. E. (1964). The ideological and legal basis of the Danish National Service, of the treatment, teaching, training, etc. of the mental retarded, as well as a description of the structure of the National Service. Paper presented at the International Copenhagen Conference on the Scientific Study of Mental Retardation, Copenhagen, Denmark.

Beier, D. C. (1964). Behavioral disturbances in the mentally retarded. In H. A. Stevens \& R. Heber (Eds.), Mental retardation: A review of research (pp. 453-487). Chicago, IL: University of Chicago Press.

Brown, H., \& Smith, H. (1989). Whose 'ordinary life' is it anyway? A feminist critique of the normalisation principle. Disability, Handicap and Society, 4(2), 105-119.

Buchanan, I. (2007). Deleuze and the internet. Australian Humanities Review, 43(December). Retrieved from http://www.australianhumanitiesreview.org/archive/ Issue-December-2007/Buchanan.html

Caruso, G. A., \& Osburn, J. A. (2011). The origins of "best practices" in the principle of normalization and Social Role Valorization. Journal of Policy and Practice in Intellectual Disabilities, 8(3), 191-196.

Clarke, A. D. B., \& Clarke, A. M. (1974). Prospects for prevention and amelioration of mental subnormality: An overview. In A. M. Clarke \& A. D. B. Clarke (Eds.), Readings from mental deficiency: The changing outlook (pp. 1-17). London: Methuen.

Corbett, A. (2011). Silk purses and sows' ears: The social and clinical exclusion of people with intellectual disabilities. Psychodynamic Practice, 17(3), 273-289.

Deleuze, G., \& Guattari, F. (1988). A thousand plateaus. London: Athlone.

Denny, M. R. (1964). Research in learning and performance. In H. A. Stevens \& R. Heber (Eds.), Mental retardation: A review of research (pp. 100-142). Chicago, IL: University of Chicago Press.

Department of Health. (2001). Valuing people: A new strategy for learning disability for the 21st century. London: HMSO.

Department of Health and Social Security. (1971). Better services for the mentally handicapped. London: HMSO.

Emerson, E. (1990). Consciousness raising, science and normalisation. Clinical Psychology Forum, 30, 36-39.

Emerson, E., \& McGill, P. (1989). Normalization and applied behaviour analysis: Values and technology in services for people with learning difficulties. Behavioural Psychotherapy, 17(2), 101-117. 
Felce, D. (1996). Changing residential services: From institutions to ordinary living. In P. Mittler \& V. Sinason (Eds.), Changing policy and practice for people with learning disabilities (pp. 127-145). London: Cassell.

Fisher, P., \& Goodley, D. (2007). The linear medical model of disability: Mothers of disabled babies resist with counter-narratives. Sociology of Health \& IIIness, 29(1), 66-81.

Flynn, R. J. (1980). Normalization, PASS, and service quality assessment: How normalizing are current human services? In R. J. Flynn \& K. E. Nitsch (Eds.), Normalization, social integration and community services (pp. 323-357). Baltimore, MD: University Park Press.

Foucault, M. (1972). The archaeology of knowledge. London: Tavistock.

Foucault, M. (1979). Discipline and punish. Harmondsworth: Penguin.

Foucault, M. (1981). The history of sexuality, volume 1: An introduction. Harmondsworth: Pelican.

Francey, R. E. (1960). Psychological test changes in mentally retarded children during training. Canadian Journal of Public Health, 51(Feb.), 69-74.

Gathercole, C. (1988). Involving people with learning disabilities. In D. Towell (Ed.), An ordinary life in practice (pp. 32-42). London: King's Fund.

Gilbert, T., Cochrane, A., \& Greenwell, S. (2005). Citizenship: Locating people with learning disabilities. International Journal of Social Welfare, 14(4), 287-296.

Goff, B. S. N., \& Springer, N. P. (Eds.). (2017). Intellectual and developmental disabilities: A roadmap for families and professionals. New York, NY: Routledge.

Goffman, E. (1961). Asylums. Harmondsworth: Penguin.

Gold, M. (1980). Try another way. Champaign, IL: Research Press.

Goodey, C. F. (2011). A history of intelligence and 'intellectual disability': The shaping of psychology in early modern Europe. London: Routledge.

Goodey, C. F. (2016). Learning disability and inclusion phobia: Past, present, future. London: Routledge.

Goodley, D. (2007). Becoming rhizomatic parents: Deleuze, Guattari and disabled babies. Disability \& Society, 22(2), 145-160.

Gutting, G. (1989). Michel Foucault's archaeology of scientific reason. Cambridge: Cambridge University Press.

Jay, P. (Chair). (1979). Report of the committee of enquiry into mental handicap nursing and care. London: HMSO.

Johnson, K., Walmsley, J., \& Wolfe, M. (2010). People with intellectual disabilities: Towards a good life? Bristol: Policy Press.

Keith, H. E., \& Keith, K. D. (2013). Intellectual disability: Ethics, dehumanization, and a new moral community. Chichester: Wiley-Blackwell.

Kendrick, M. (1999). The impact of normalization and social role valorization in the English-speaking world. In R. J. Flynn \& R. A. Lemay (Eds.), A quarter-century of normalization and social role valorization: Evolution and impact (pp. 425-436). Ottawa: University of Ottawa Press.

King's Fund. (1980). An ordinary life: Comprehensive locally-based residential services for mentally handicapped people. London: King's Fund.

King's Fund. (1984). An ordinary working life. London: King's Fund.

Kittay, E. F., \& Carlson, L. (Eds.). (2010). Cognitive disability and its challenge to moral philosophy, Chichester: Wiley-Blackwell.

Kuhn, T. (1996). The structure of scientific revolutions. Chicago, IL: University of Chicago Press.

Mathews, I. (2017). Not like us? Wolfensberger's 'major historic roles' reconsidered. Disability \& Society, 32(9), 1351-1365.

Meyerson, L., Kerr, N., \& Michael, J. L. (1974). Behaviour modification in rehabilitation. In D. M. Boswell, \& J. M. Wingrove (Eds.), Handicapped person in the community (pp. 377-391). London: Tavistock/Open University.

Nayar, P. (2014). Posthumanism. Cambridge: Polity.

Nirje, B. (1969). The normalization principle and its human management implications. In R. B. Kugel, \& W. Wolfensberger (Eds.), Changing patterns of residential care for the mentally retarded (pp. 179-195). Washington, DC: Presidential Committee on Mental Retardation.

Nirje, B. (1972). The right to self-determination. In W. Wolfensberger (Ed.), The principle of normalization in human services (pp.176-193). Toronto: National Institute of Mental Retardation.

Nirje, B. (1992). The normalization papers. Uppsala: Uppsala University, Center for Handicap Research.

O'Brien, J. (1981). The principle of normalisation: A foundation for effective services. London: $\mathrm{CMH}$.

O'Connor, N., \& Tizard, J. (1956). The social problem of mental deficiency. London: Pergamon.

Parmenter, T. (2004). Historical overview of applied research in intellectual disabilities: The foundation years. In E. Emerson, C. Hatton, T. Thompson, \& T. Parmenter (Eds.), The international handbook of applied research in intellectual disabilities (pp. 3-40). Chichester: John Wiley and Sons.

Perrin, B., \& Nirje, B. (1985). Setting the record straight: A critique of some frequent misconceptions of the normalization principle. Australia and New Zealand journal of developmental disabilities, 11(2), 69-74.

Philp, M. (1990). Michel Foucault. In Q. Skinner (Ed.), The return of grand theory in the human sciences (pp. 65-81). Cambridge: Cambridge University Press.

Race, D. G. (2002). The 'normalisation' debate: Time to move on. In D. G. Race (Ed.), Learning disability: A social approach (pp. 191-208). London: Routledge.

Richards, S. B., Brady, M. P., \& Taylor, R. L. (2015). Cognitive and intellectual disabilities: Historical perspectives, current practices, and future directions (2nd ed.). New York, NY: Routledge.

Rogers, C. (2016). Intellectual disability and being human: 
A care ethics model. London: Routledge.

Ryan, J., \& Thomas, F. (1987). The politics of mental handicap. London: Free Association Books.

Schalock, R. (2004). Adaptive behavior: Its conceptualization and measurement. In E. Emerson, C. Hatton, T. Thompson, \& T. Parmenter (Eds.), The international handbook of applied research in intellectual disabilities (pp. 369-384). Chichester: John Wiley and Sons.

Scottish Executive. (2000). The same as you? A review of services for people with learning disabilities. Edinburgh: Scottish Executive.

Scottish Government. (2013). The keys to life: Improving quality of life for people with learning disabilities. Edinburgh: Scottish Government

Shevellar, L., Sherwin, J., \& Mackay, G. (2012). A reimagined identity: building a movement in Brisbane for the practice of Social Role Valorization. In P. Westoby \& L. Shevellar (Eds.), Learning and mobilising for community development: A radical tradition of community-based education and training (pp. 81-94). Farnham: Surrey.

Shildrick, M. (1997). Leaky bodies and boundaries: Feminism, postmodernism and (bio)ethics. London: Routledge.

Shildrick, M., \& Price, J. (2006). Deleuzian connections and queer corporealities: Shrinking global disability. Rhizomes, 11(Fall/Spring). Retrieved from http:// www.rhizomes.net/issue11/shildrickprice/index.html

Simpson, M. K. (1998). The roots of normalisation: A reappraisal: Guest editorial. Journal of Intellectual Disability Research, 42(7), 1-7.

Simpson, M. K. (2014). Modernity and the appearance of idiocy: Intellectual disability as a regime of truth. Lampeter: Edwin Mellen Press.

Simpson, M. K. (2017). The subject of intellectual disability: A reply to Clegg, Murphy and Almack. Philosophy, Psychiatry \& Psychology, 24(4), 373-376.

Sturmey, P., \& Didden, R. (Eds.). (2014). Evidence-based practice and intellectual disabilities. Malden, MA: John Wiley \& Sons.

Sullivan, M. (2005). Subjected bodies: Paraplegia, rehabilitation, and the politics of movement. In S. Tremain (Ed.), Foucault and the government of disability (pp. 27-44). Ann Arbor, MI: The University of Michigan Press.

Szivos, S. (1991). Consciousness-raising: An attempt to redress the more repressive aspects of normalisation, but not its more positive ones. Clinical Psychology Forum, 33(June), 28-31.

Szivos, S., \& Travers, E. (1988). Consciousness raising among mentally handicapped people: A critique of the implications of normalization. Human Relations, 41(9), 641-653.

Thomas, S., \& Wolfensberger, W. (1999). An overview of Social Role Valorization. In R. J. Flynn \& R. A. Lemay (Eds.), A quarter-century of normalization and social role valorization: Evolution and impact (pp. 125-159). Ottawa: University of Ottawa Press.

Tizard, J. (1964). Community services for the mentally handicapped. Oxford: Oxford University Press.

Towell, D. (Ed.). (1988). An ordinary life in practice. London: King's Fund.

Valle, E. (1997). A scientific community and its texts: A historical discourse study. In B.-L. Gunnarsson, P. Linell, \& B. Nordberg (Eds.), The construction of professional discourse (pp. 76-98). London: Longman.

Wolfensberger, W. (1970). The principle of normalization and its implications for psychiatric services. American Journal of Psychiatry, 127(3), 291-297.

Wolfensberger, W. (1971). Will there always be an institution? I: The impact of epidemiological trends. Mental Retardation, 9(5), 14-20.

Wolfensberger, W. (1972). The principle of normalization in human services. Toronto: National Institute of Mental Retardation.

Wolfensberger, W. (1975). The origin and nature of our institutional models. Syracuse: Human Policy Press.

Wolfensberger, W. (1980). The definition of normalization: Update, problems, disagreements, and misunderstandings. In R. J. Flynn \& K. E. Nitsch (Eds.), Normalization, social integration and community services (pp. 71-115). Baltimore, MD: University Park Press.

Wolfensberger, W. (1983). Social Role Valorization: A proposed new term for the principle of normalization. Mental Retardation, 21(6), 234-239.

Wolfensberger, W. (1995). Social Role Valorization is too conservative. No, it is too radical. Disability \& Society, 10(3), 365-368.

Wolfensberger, W. (2002). Social Role Valorization and, or versus, 'empowerment'. Mental Retardation, 40(3), 252-258.

Wolfensberger, W., \& Thomas, S. (2007). PASSING: A tool for analyzing service quality according to social role valorization criteria: Ratings manual (3rd ed.). Syracuse, NY: Training Institute for Human Service Planning, Leadership and Change Agentry (Syracuse University).

Yates, S., Dyson, S., \& Hiles, D. (2008). Beyond normalization and impairment: Theorizing subjectivity in learning difficulties-Theory and practice. Disability \& Society, 23(3), 247-258. 


\section{About the Author}

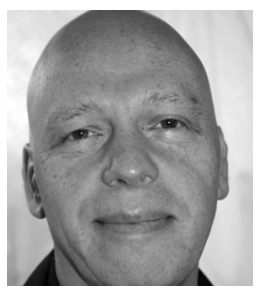

Murray Simpson is a Reader at the School of Education and Social Work, University of Dundee in Scotland. He has published widely on the conceptual history of intellectual disability. His doctoral thesis outlined the emergence of intellectual disability as a discursive field linked to modernity. Current work includes the analysis of the location of intellectual disability within psychiatric discourse, disability and signification in cinema, and the application of Giorgio Agamben's work to disability. 